\title{
Atypical localizations of the basal cell carcinoma: series of 12 cases
}

\section{Ibtissam Assenhaji, Hanane Baybay, Kaoutar Achehboune, Zakia Douhi, Sara Elloudi, Fatima Zahra Mernissi}

Department of Dermatology CHU Hassan II Fez, Morocco

Corresponding author: Dr. Ibtissam Assenhaji, E-mail: Assenhaji.louizi@outlook.fr

Sir,

Basal cell carcinoma (BCC) often affects the cephalic extremity, rarely the photoprotected areas 10 to $15 \%$ of cases [1].

We report a series of 12 BCC cases with unusual localization.

This is a retrospective study from 2015 to 2018 collecting all cases of BCC with unusual localization over 290 cases of BCC followed in the Dermatology Department CHU Hassan II of Fez, Morroco.

We collected twelve patients followed for BCC in unusual locations such as three in the back, three in the trunk (Figs. 1 and 2), and one the shoulder (Fig. 3), the sacral region (Fig. 4), the knee (Fig. 5), the leg, the elbow crease and one on a precursor lesion of hamartoma Jadassohn (Fig. 6).

The mean age at diagnosis was 59 years ( 35 to 82 years) with a male predominance; the phototype ranged from 3 to 4 , the average consultation time was 4 years ( 1 to 12 years), no risk factors were found. The symptoms motivating the consultation were most often ulceration and increase in size.

Clinical examination found ulcero-budgeonnanneur tumors in $50 \%$ of cases, plaques ulcerated in $25.7 \%$; nodules in $16 \%$, and papules pigmented in $8.3 \%$. The lesions averaged $20.5 \mathrm{~mm}$ (10 to $40 \mathrm{~mm}$ ). The dermoscopic signs were in favor of CBC. The diagnosis of basal cell carcinoma was confirmed by histology.
The histological study concluded with a nodular CBC in $75 \%$, superficial in $16.6 \%$, nodular pigmented in $8.4 \%$.

Surgical excision was required in all cases with healthy margins. The evolution was good in 12 of the cases with a free good evolution.

The prevalence of uncommon BCCs in our series is lower than that reported in the literature 10-15\% [1]. The consultation period was late in our series, which can be explained by the occurrence of CBCs in hidden areas.

In non-photo-exposed areas, other undetermined etiological factors than UV exposure would also play an important role in their occurrence of $\mathrm{CBCs}$, such as vesmodegib mutation abnormalities during Gorlin's syndrome, radiotherapy, immunosuppression [2], not found in our series. Regarding the occurrence of BCC on a precursor lesion such as hamartoma Jadassohn, it is reported in less than $1 \%$ in the literature [3].

Dermoscopy allows the presumptive diagnosis of BCC in these unusual locations, but the confirmation is histological. Nodular BCC represents the histological subtype most commonly reported for these forms [1], consistent with our data. The evolution depends on the possibility of a complete excision with healthy margins $[1,4]$, which varies according to the localizations. Indeed, it was favorable in all our patients with a satisfactory decline in most cases.

Our series illustrates the unusual locations of BCCs in non-photo-exposed areas, but not exceptional,

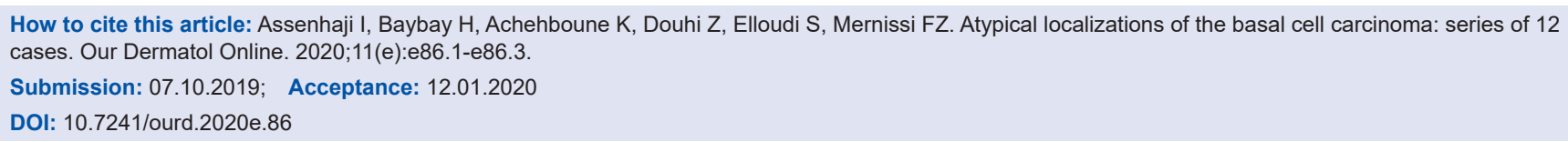




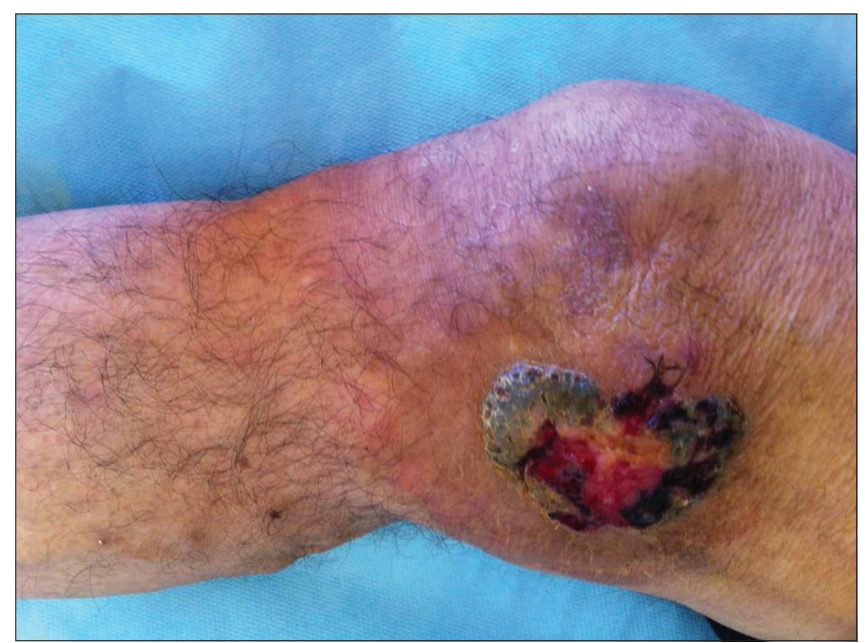

Figure 1: Basal cell carcinoma on the trunk.

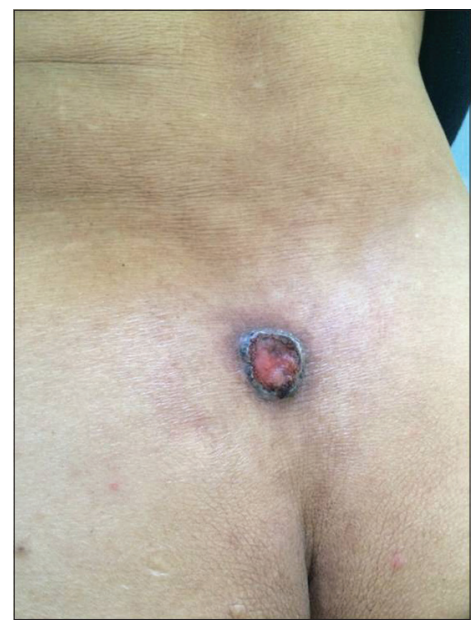

Figure 2: Basal cell carcinoma on the thorax.

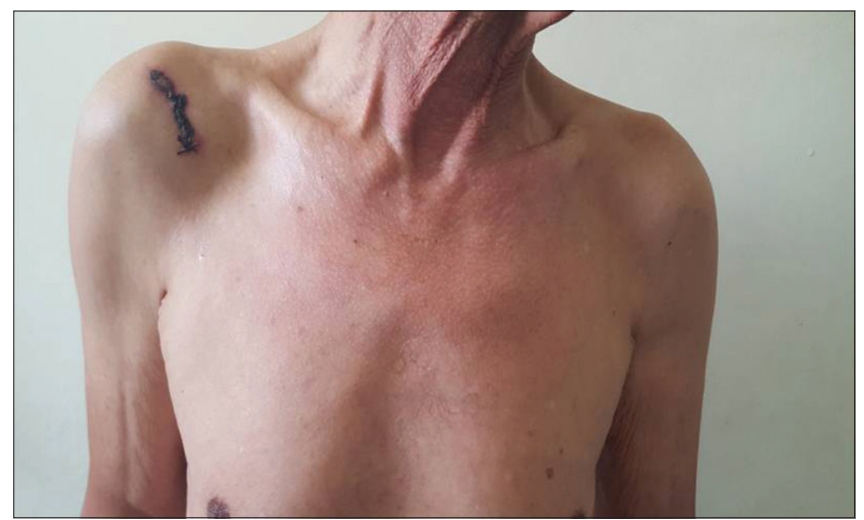

Figure 3: Basal cell carcinoma on the shoulder.

justifying a complete clinico-dermoscopic cutaneousmucosal examination.

\section{Consent}

The examination of the patient was conducted according to the Declaration of Helsinki principles.

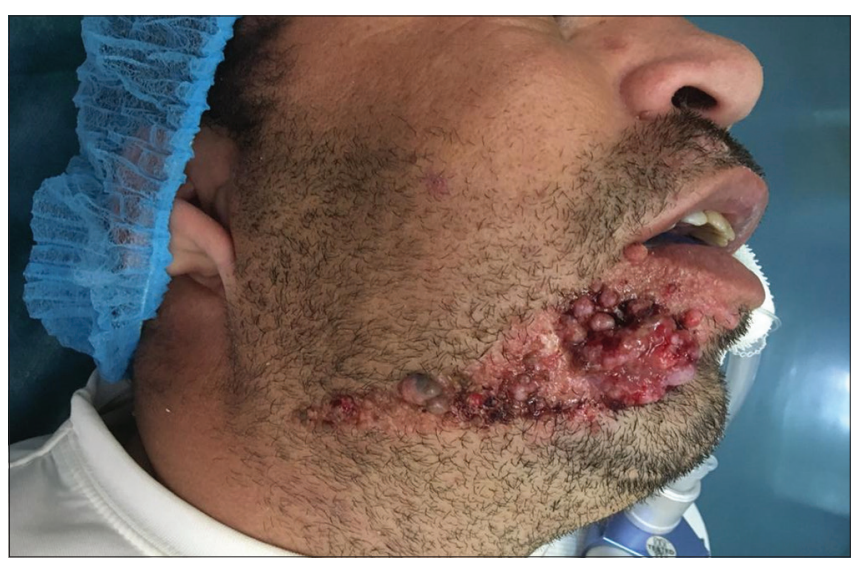

Figure 4: Basal cell carcinoma of the sacred region.

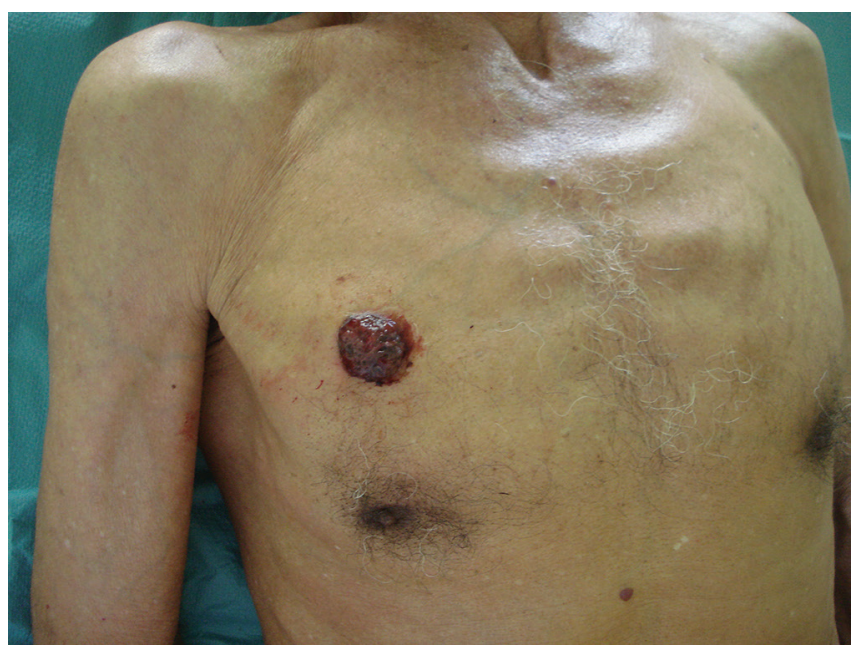

Figure 5: Basal cell carcinoma on right knee.

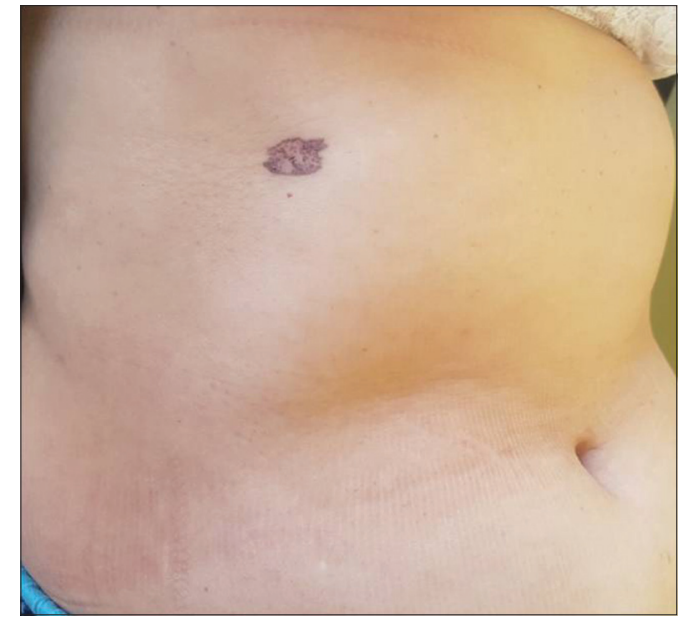

Figure 6: Basal cell carcinoma on naevus of Jadassohn.

The authors certify that they have obtained all appropriate patient consent forms. In the form the patient(s) has/have given his/her/their consent for his/her/their images and other clinical information to be reported in the journal. The patients understand that their names and initials will not be published and due efforts 
will be made to conceal their identity, but anonymity cannot be guaranteed.

\section{REFERENCES}

1. Ouédraogo MS, Korsaga/Somé N, Ouédraogo AS, Ouédraogo NA, Tapsoba GP, Konsem T, et al. [Epidermoid carcinoma involving on chronic ulcer of the upper lip in a patient infected with HIV]. Our Dermatol Online. 2016;7:431-5.

2. Bartoš V, Kullová M. Immunohistochemical evaluation of E-cadherin expression in basal cell carcinoma of the skin. Our
Dermatol Online. 2015;6:257-64.

3. Tiwary AK, Mishra DK. Jadassohn Lewandowsky syndrome: Type 1 pachyonychia congenita. Our Dermatol Online. 2017;8:56-9.

4. Bartoš V, Bulejčíková T. Basal cell carcinoma of the skin with clear cell differentation: A report of two cases. Our Dermatol Online. 2016;7:422-6.

Copyright by Ibtissam Assenhaji, et al. This is an open-access article distributed under the terms of the Creative Commons Attribution License, which permits unrestricted use, distribution, and reproduction in any medium, provided the original author and source are credited.

Source of Support: Nil, Conflict of Interest: None declared. 